\title{
Examining the Effect of Amanah Ikhtiar Malaysia's Microcredit Program on Microenterprise Assets in Rural Malaysia
}

\author{
Abdullah- Al- Mamun (Corresponding author) \\ Centre for Social Entrepreneurship, Binary University College, 47100 Puchong, Malaysia \\ Tel: 60-16-215-7752 E-mail: mamun.freethinker@gmail.com, abdullah@binary.edu.my \\ Joseph Adaikalam \\ Centre for Social Entrepreneurship, Binary University College, 47100 Puchong, Malaysia \\ Tel: 60-3-8070-6590 E-mail: joseph@binary.edu.my \\ Mohammad Nurul Huda Mazumder \\ Faculty of Management, Multimedia University, 63100 Cyberjaya, Malaysia \\ Tel: 60-3-8312-5691 E-mail:mohammad@mmu.edu.my
}

\author{
Received: September 21, $2011 \quad$ Accepted: December 19, $2011 \quad$ Published: April 1, 2012 \\ doi:10.5539/ass.v8n4p272 \\ URL: http://dx.doi.org/10.5539/ass.v8n4p272
}

This study was conducted under the project titled "Fighting Against Poverty" funded by the Centre for Social Entrepreneurship, Binary University College

\begin{abstract}
Microenterprise often considered as an antecedent for generating income and employment, which leads to a decline in overall poverty rate and other aspects of sustainable socio-economic development. The objective of this study is to identify the impact of Amanah Ikhtiar Malaysia's (AIM) microcredit program on microenterprise assets owned by poor women in rural Peninsular Malaysia. In order to advance our understanding on the topic, contribute to the existing literature and to obtain the above mentioned objective, we employed a cross sectional design with stratified random sampling method. Data was collected from 281 rural clients selected from seven branches in five states in Peninsular Malaysia. Findings showed that the current market value of livestock's, agricultural/production equipments, agricultural stock/raw materials, enterprise assets and motor vehicles owned by old client respondents were relatively higher than that of new client respondents. Study also revealed that the mean market value of microenterprise assets owned by old clients is significantly higher than that of new clients. Therefore, there is a need to give emphasis on providing adequate training, favorable environment, and flexible and diversified loan programs in order to promote sustainable microenterprise development.
\end{abstract}

Keywords: Microcredit, Poverty, Microenterprise, Assets, Malaysia

\section{Introduction}

Reducing poverty and unemployment rate through promoting microenterprise development are often the most frequently stated objective of sustainable socio-economic development programs. As well paid employment opportunities are limited in developing economies; a large segment of the population tends to push for more profitable alternatives which resulted in increasing the rate of new microenterprises (ADB, 1997). As reported by ADB (1997), microenterprises account for more than $60 \%$ of all enterprises and up to $50 \%$ of paid employment. The overwhelming growth of microenterprises in Asian economies is remarkable as they contribute significantly to the development of these emerging economies. The growth rate might surpass other stakeholders of businesses in terms of their contribution to GDP of these economies. Access to finance, business development training and supportive environment are considered as the key elements for the development of sustainable 
microenterprises (USAID, 2011). The vital role of microfinance organizations in developing microenterprises are well documented in the microenterprise development literature.

Microenterprises are generally owned by low-income households, are, therefore, found to be the most vulnerable to decapitalization to meet household requirements in all types of emergencies. As mentioned by ADB (1997), fixed assets and inventories are often sold to meet the consumption requirement, which bring the microenterprise to its end. Supportive financial services can support and promote microenterprise development by providing a safety net of essential social services, consumptions and emergencies. Microfinance organizations of all over the world are providing supportive financial services for microenterprise development. Microcredit is a collection of banking practices appeared to provide small loans and accept small saving deposits. Microcredit, as defined by Robinson (2001), is a small scale financial services - commonly credit and savings - provided to poor and hardcore poor people who farm, fish or herd. The Asian Development Bank (2009) defines microcredit as the provision of a wide range of financial services which includes small amount of loans, small deposits and microinsurance to poor microentrepreneurs. Since microcredit has been providing financial supports as a development initiative commonly to the poor rural women in order to enable them to initiate or improve the income generating activities through microenterprises, it is therefore expected that the small amount of collateral free credit and training provided by Amanah Ikhtiar Malaysia would lead to an increase in microenterprise assets owned by poor clients and their households in rural Peninsular Malaysia.

\subsection{Microcredit and Microenterprise Assets}

Assets, important indicator of household's economic well-being, are commonly considered to be more stable over time. They are the stock of wealth; therefore represent the long-term effects of income flows and expenditures (Barnes, 1996). As assets are the foundation of future consumption and wealth, therefore, they are considered as important indicator while measuring the impact of microcredit programs. When micro entrepreneurs utilized the received microcredit to accumulate assets, it increases the asset directly. Microcredit helps generate additional income and stock of capital as a result of multiplier effect as Barnes (1996) pointed out that the additional assets also lead to an increase in income and further accumulation of assets. Microcredit also enables micro entrepreneurs to better manage existing assets, ability to take risk and reduce liabilities. These factors are expected to lead to an increase in microenterprise assets owned by borrower's households.

Within the expanding scope of microcredit, it is necessary to provide solid definition of microenterprise in order to understand the potential contribution of microcredit on microenterprise assets. Microenterprise, as defined by ADB (1997), is a 'non-crop enterprises employing less than ten workers, including the owner-operator and family workers'. ADB's (1997) definition of microenterprise also implied an implicit income and asset limit because as they reported 'it is widely understood that microenterprises are enterprises of the poor'. The concept of 'implicit income and asset limit' is not widely practiced in order to identify microenterprises. As mentioned by Alam and Miyagi (2004), commonly microenterprises in Bangladesh are engaged in poultry, livestock, dairy, rice/oil mills, agricultural equipment making, and trading in inputs such as seeds and fertilizers, to non-firm enterprises such as petty trading, small business in transport, timber, bakery, medicine/pharmacy, and enterprise manufacturing bricks, ring slabs. Because of the difficulties in defining microenterprise by sectors, the government commonly sets the label based on the value of the total microenterprise assets. As in Bangladesh, if the total value of the capital invested in the business is less than BDT1 million (about USD15000) is considered as microenterprise (Alam and Miyagi, 2004). In Malaysia, the National SME Development Council defines micro enterprises as companies with sales turnover of less than RM250,000 or full time employee less than 5 for manufacturing/agro-based industry or sales turnover of less than RM200,000 or full time employees less than 5 for others (Bank Negara Malaysia, 2004). From the previous discussions, we can conclude that microenterprise assets are measured as the net worth of livestock, agricultural/production equipments and stocks, enterprise assets, vehicles and orchard minus liabilities. Liability includes all formal and informal debts.

\subsection{Study Context: Amanah Ikhtiar Malaysia (AIM)}

AIM established in 1987, usually provides small scale financial services and training to poor and hardcore poor only, in order to improve their socio-economic condition. AIM follows group based Grameen Bank (a Bangladeshi microfinance organization) microfinancing model, which has been simulated by many MFO's all over the world. The client selection procedure of AIM starts with measuring potential clients' average monthly household income. Households with average monthly household income below the poverty line income (Poverty Line Income or PLI has been calculated by the Malaysian government since the year 1976. It was estimated based on the necessity of food and other basic needs) would be considered as absolute poor, while households with average monthly household income below half of the PLI would be categorized as hardcore poor. Therefore, 
households whose average monthly household income falls below the PLI, including both poor and hardcore poor households, are considered to be eligible to obtain microcredit from AIM. AIM offers three economic loans namely I-Mesra loan, I-Srikandi loan and I-Wibawa loan. AIM also provides I-Penyayang loan or recovery loan. In addition, AIM provides education loan (I-Bistari) and housing/multipurpose loan known as I-Sejahtera. In the provision of AIM practices, no legal action is used to deploy if the borrowers fail to settle their payments. As of August 2010, AIM has extended their outreach to 87 branches in Malaysia. There are 60497 groups in 6646 centers, currently serving a total of 254,116 clients with a $99.42 \%$ repayment rate (AIM, 2010). Since AIM is the only microfinance organization operating at national level and outreached more than $82 \%$ of the poor and hardcore poor households in Malaysia, this study therefore selected AIM in order to measure the impact of microcredit program on microenterprise assets owned by poor rural households in Peninsular Malaysia.

\section{Review of Literature}

Extensive and up-to-date literatures on the positive role of microcredit organization on microenterprise development are available in socio-economic development literatures. The importance of such literatures is uprising in economic literatures as microcredit becomes a phenomenon in reducing poverty as well as generating microenterprises. As reported by Alam and Miyagi (2004), MFO's (Microfinance Organizations) provided microcredit to $44.49 \%$ in small business, $17.73 \%$ in livestock rearing, $12.74 \%$ in agriculture and $4.84 \%$ in fishing sector in Bangladesh. The studies conducted to measure impact of microcredit on microenterprise developments indicate a positive effect of microcredit on microenterprises. Study conducted by Hossain (1988) noted that the amount of working capital invested in client's microenterprise, increased by an average of three times within a period of 27 months. The investment in fixed assets is about 2.5 times higher for the clients with more than three years' membership than for those who joined during the year of the survey. About one third of the members were unemployed before joining microfinance program (Hossain, 1988). A study conducted by Sutoro (1990) showed that respondents' enterprise income increased by $93 \%, 26 \%$ of increase appeared in the ownership of productive machineries, about $16 \%$ increase in the ownership of business vehicle and $76 \%$ of increase in household income. Sebstad and Walsh (1991) also noted a positive impact of microcredit on microenterprise sales. Mosley (1996) conducted a study in Bolivia and noted that respondents enterprise income increased by $91 \%, 39 \%$ borrowers became employed after participation and $26 \%$ used loan for new technology mostly sewing machines. Kamal (1999), when measuring the impact of ASA's (Association for Social Advancement) microcredit programs in Bangladesh, noted that $90.42 \%$ of the sampled respondents reported an increase in business capital after participation. Dunn and Arbuckle (2001) conducted a study in Peru where the authors found that there were substantial increase in microenterprise income, asset and employment among participants than that of non-participants. The study of Islam (2007) pointed out that borrowing working capital by poor clients' increases investment in working capital and assets. The study of Rahman, Rafiq and Momen (2009) mentioned that age, education and number of gainfully employed members had a significant positive effect on household income and asset. Panda (2009) in his study in India asserted a significant increase in borrower's household income (11.41\%) and asset position was $9.75 \%$ higher than non participants and the savings increased by $42.53 \%$. A positive link between microcredit and employment was also explored in this study. Panda (2009) also noted an increase in annual employment days among the clients.

Studies that estimated the impact of AIM's microcredit schemes showed a similar positive effect. Gibbons and Kasim (1990) showed a significant increase of client's monthly household income from an average of RM142 per month to RM220. Their study also illustrated that the female participants experienced a higher increase in monthly household income compared to male participants. The Second Internal Impact Study (1990) was conducted by AIM's research and development unit. This study showed further overall improvement among participating households' living standard. The government of Malaysia initiated an impact assessment study on AIM's microcredit schemes by a team of Social Science and Economic Research Unit (SERU) of the Prime Ministers Department in 1990. SERU (1990) noted that the overall household income was more than double for those households who participated in AIM's microcredit schemes. The SERU study also found a significant impact on household's quality of life, which is based on the ownership and quality of housing, type and quality of household assets, agricultural land and savings. The increase in household income also facilitated an increase in expenditure on food, nutrition, education and reinvestment. The Third Internal Impact Study (1994) reconfirmed the earlier findings in non-monetary impact of microcredit on poor households. This study also found an improvement in the percentage of owner occupied house to $85 \%$ compared to $80 \%$ prior to participation. The use of electric household products also showed some slight improvements. Study conducted by Salma (2004) translated that the household income, expenditure, savings and assets have increased for both AIM and PPRT (Projek Perumahan Rakyat Termiskin) participants compared to non-participants. It is important 
to note here that, these increases are higher for AIM clients than PPRT clients. Salma (2004) concluded that the microcredit program generated direct and higher contribution to generate income than non microcredit programs. A recent study conducted by Saad (2010) indicates a positive effect in human development in rural Malaysia, including improved health condition of the clients as well as improved education level of clients' children. Saad (2011) in her study titled 'Selecting High-Income Generating Activities for Micro-entrepreneurs: The Case Study of Amanah Ikhtiar Malaysia', identified that economic activity in the trading sector were more beneficial for the clients than other activities. Activities that generate high income include rubber trading, sales of cooking gas, hawking night market, sales of cosmetics, paint products, used cars health products, and food.

\section{Research Methods}

\subsection{Research Hypothesis}

As mentioned by Hulme (1997), "behind all microfinance programs is the assumption that intervention will change human behaviors and practices in ways that will lead to the achievement (or raise the probability of achievement) of desired outcomes." The conceptual model of impact chain presents a complex set of links as each 'effect' becomes a 'cause' in its own right generating further effects. One of the most complex conceptual models for impact assessment was presented by Chen and Dunn (1996), called Household Economic Portfolio Model (HHEP). The researchers confirmed the usefulness of HHEP model in addressing the fungibility and attribution issues. In this research, hypothesis was used to test only a portion of the implications given by the model. The objective of this study is to measure the effect of AIM's microcredit program on microenterprise assets in rural Peninsular Malaysia. In support of the research objective, the following specific alternative hypothesis is investigated: Hypothesis $1\left(H_{1}\right)$ : Participation in AIM's microcredit program leads to an increase in the current market value of microenterprise assets owned by poor rural households in Peninsular Malaysia.

\subsection{Research Design}

As mentioned by Montgomery and Weiss (2011), impact assessment methodology addresses how participation in microcredit program affects the selected variables with how those same selected variables would be in the absence of microcredit program. The most appropriate method to address the question would be by employing an experimental design. Since it is just not possible to control all the factors while measuring the impact of microcredit (Hulme, 2000), therefore, full experimental approach is not feasible for assessing the impact of microcredit programs (see also Khandker and Pitt, 1998; Swain and Varghese, 2009; Montgomery and Weiss, 2011). This study uses a quasi-experimental approach to measure the impact of microcredit. In quasi-experimental approach control and treatment groups are used to measure the impact of AIM's microcredit programs. This study selects control and treatment groups from AIM's client base. The control group are those participating less than or equal to 60 months and the treatment group as those participating more than 60 months.

This research employed a cross-sectional design to measure the impact of AIM's microcredit schemes in rural Peninsular Malaysia. It is adopted the group statistics that has been most often known as 'average effect of treatment of treated', which measures the impact on the outcome of one group compared to others. The average program impact is estimated by comparing the average outcome of the members of treatment group (old respondents) with the same average outcome of the members of the control group (new respondents).

\subsection{Sample Selection and Data Collection}

This research employed a stratified random sampling method and collected data through face-to-face structured interviews. AIM's microcredit program currently offers financial services through 87 branches in 13 states in Malaysia. Among the 87 branches, 7 branches were randomly selected from five states, where poverty rate is relatively higher compared to other states. Out of seven branches, two were from Kedah (Cawangan Baling and Cawangan Pendang), two were from Kelantan (Cawangan Machang and Cawangan Tumpat) and one branch each from Perlis (Cawangan Perlis), Perak (Cawangan Batang Padang) and Terengganu (Cawangan Besut). A team of nine Research Assistants together with the Project Manager then visited each of the branches from $18^{\text {th }}$ April, 2011 to $9^{\text {th }}$ May, 2011. Respondents were randomly selected during the centre meetings. After the data collection team had explained the purpose of the study a total of 286 respondents agreed to be interviewed and complete data were collected from a total of 281 poor rural clients, of whom 99 were new clients (participating AIM's microcredit program for less than or equal to 60 months) and 182 were old clients (participating AIM's microcredit program for more than 60 months).

\section{Summary of Findings}

Participation in AIM's microcredit program conceptualized by two indicators, number of months as client and total amount of credit received. The mean number of months among selected old clients was 122.54 months with 
a standard deviation of 46.68 , which is significantly higher ( $p$-value of Mann-Whitney Test is 0.00 , which is less than the chosen $5 \%$ level of significance) than the mean number of months new clients participating AIM's microcredit program -26.42 months with a standard deviation of 19.02 . The mean amount of credit received by old respondents was RM24642.30 with a standard deviation of RM28531.77. The mean amount of credit received by new respondents was RM8347.47 with a standard deviation of RM8916.05. It was noted that the deviation in the distribution of total amount of credit received by all clients was very high, due to the level of 'need for credit' and 'opportunity to invest credit in economic activities'. The $p$-value for Mann-Whitney test is 0.000 , which is less than the chosen $5 \%$ level of significance, indicating that the total amount of credit received by old respondents also significantly higher than the new respondents.

In order to investigate the effect of microcredit on microenterprise assets, it is important to explore how respondent used the credit they received. As presented in Table 1 , only $36.7 \%$ of the total respondents reported that they used entire amount of credit they received from AIM in economic activities. For new and old respondents these rates are $68.7 \%$ and $19.2 \%$ respectively. This clearly indicated that among the sampled clients higher proportion of old respondents did not used credit in economic activities. Therefore, AIM needs to identify old clients using credit in non-economic activities and the risk associated with the trend of using credit in non-economic activities. However, data were also collected on the proportion of loan respondent using in economic activities. It is noted that on average, about $80 \%$ of the total loan received by respondents used in economic activities.

This study also investigated the type of economic activities respondents used the credit received from AIM's rural microfinance program. As shown in Table 1, only 13 out of 281 respondents or $4.6 \%$ of them reported that they invested credit in manufacturing activities. For new and old respondents these numbers were 3 out of 99 and 10 out of 182 respectively. It is noted that 123 out of 281 respondents or $43.8 \%$ of them, which was the highest proportion of respondents, invested the loan they received in trade or retail activities. $46.2 \%$ of the old respondents reported that they invested loan in trade or retail activities, which was higher than the proportion of new respondents. About $39.4 \%$ used loan in trading or retail activities. The proportion of respondents who used credit for service, agriculture/fishing and other activities were $14.6 \%, 32.7 \%$ and $3.9 \%$ respectively. The $p$-value for Pearson's Chi-Square test was 0.614 , which was higher than chosen $5 \%$ level of significance, indicating no association between types of economic activities for which respondents use the loan and respondent's participation status - new and old.

The number of respondents, proportion of respondents, mean and standard deviation of current market value of livestock assets, agricultural and/or production equipments, agricultural stock/raw materials, enterprise assets, vehicles and orchard are presented in Table 2. As shown in Table 2, out of total 281 respondents, only 29 of them reported to have livestock assets. The mean market value of livestock owned by old respondents is relatively higher than that of new respondents. Only 24 out of 281 respondents or $8.5 \%$ of the respondents reported to have agricultural / production equipments. It was noted that the mean market value of agricultural/production equipments owned by old respondents also much higher than that of new respondents. In regard to agricultural stock or raw materials, $27.0 \%$ of the total respondents reported to own them. However, a relatively higher proportion of new respondents owned agricultural stock or raw materials and the mean market value of agricultural stock or raw materials owned by old respondents was much higher than that of new respondents.

163 out of 281 respondents or $58 \%$ of the respondents reported to have enterprise assets. The highest proportion of respondents owning enterprise assets indicated that a huge proportion of clients were involved in small-scale enterprise activities. The mean market value of enterprise assets owned by new respondent's RM5723.70 with a standard deviation of RM3910.80. It was also noted that the mean market value of enterprise asset owned by old respondents, which is RM10541.92 with a standard deviation of RM8859.07, were relatively higher than that of new respondents.

In regard to motor vehicles, 210 out of 281 rural clients or $74.7 \%$ of them reported that their households owned motor vehicles. The proportion of new and old respondents households own motor vehicles were $80.78 \%$ and $71.4 \%$. The mean market value of motor vehicles owned by new respondents was RM7347.50 which was lower than RM8366.15, the mean market value of motor vehicles owned by old respondents. It was noted that the deviation in the distribution of approximate market value of motor vehicles owned by respondents households were very high. The mean market value of orchard owned by 27 new respondents' households was RM3122.22 with a standard deviation of RM2482.60. 
In regards to savings, the mean amount saved by new respondents was RM446.36 with a standard deviation of RM171.93. The mean amount of savings by old respondents households were RM758.62 with a standard deviation of RM989.52. as of unpaid loan, as shown in Table 2, 209 out of 281 respondents or $74.4 \%$ of them reported to have unpaid loan. The mean amount of unpaid loan among new respondents was RM3053.68 with a standard deviation of RM3335.73. The mean amount of unpaid loan for old respondents was RM5986.36 with a standard deviation of RM7604.60.

\subsection{Testing Research Hypothesis}

The market value of microenterprise assets owned by respondents was calculated by adding the current market value of livestock assets, agricultural and/or production equipments, agricultural stock/raw materials, enterprise assets, vehicles and orchard owned by respondent's households, savings and unpaid loan is subtracted from the total. The mean and standard deviation of the market value of microenterprise assets owned by respondents presented in Table 3. It is important to note that the mean market value of microenterprise assets owned by old respondents' households was higher than that of new respondents. The $p$-value of Shapiro-Wilk test of normality was 0.000 , which was less than chosen $5 \%$ level of significance, indicating that the normality assumption was violated. A non-parametric Mann-Whitney test was therefore conducted. The $p$-value for Mann-Whitney test was 0.000 , which is less than the chosen $5 \%$ level of significance, indicating that the mean market value of microenterprise assets owned by old respondents were significantly higher compared to new respondents. Result showed that participation in AIM's microcredit program led to an increase in microenterprise assets owned by client's households in rural Peninsular Malaysia.

\section{Conclusion and Recommendations}

The primary objective of AIM's microcredit projects is to improve the income generating activities trough providing access to financial services and training. Findings of this study indicates that respondents participating significantly higher number of month as client are receiving significantly higher amount of credit, current market value of the assets - livestock's, agricultural/production equipments, agricultural stock/raw materials, enterprise assets and motor vehicles owned by them (old clients) were relatively higher than that of new respondents. A relatively higher proportion of old respondents also reported to use credit in trade or retail activities than that of new respondents. Study also revealed that the mean market value of microenterprise assets owned by old respondents is significantly higher than that of new respondents. This indicates the positive effect of AIM's microcredit program on microenterprise assets in rural Peninsular Malaysia. In order to foster the development, AIM should, therefore, review the current policy and microcredit methodology and offer more diversified products and services. Clients need for consumption credit or a safety net program is vital for promoting microenterprise development. The credit services can be diversified by expanding group loan size, provide working capital loan, fixed asset loan, seasonal agricultural loan, car loan, consumer loan, emergency loan and parallel loan.

\section{References}

ADB - Asian Development Bank. (1997). Microenterprise Development: Not By Credit Alone. [Online] Available: http://www.adb.org/Documents/Books/ Microenterprise /microenterprise.pdf (09.01.2010)

ADB - Asian Development Bank. (2009). Microfinance Development Strategy. [Online] Available: http://www.adb.org/Documents/Policies/Microfinance/microfinance0100.asp?p=policies (12.01.2009)

Alam, C. M. and Miyagi, K. (2004). An approachable analysis of Micro Enterprises in Bangladesh, Working Paper no 8, Department of International Studies, Hagi International University, Japan. [Online] Available: http://www.kitakyu-u.ac.jp/gkj/files/sr004101mk.pdf (12.05.2009)

Amanah Ikhtiar Malaysia. (2010). Achievement as of 31 August 2010. [Online] Available: http://www.aim.gov.my (09.12.2010)

Bank Negara Malaysia. (2004). Conclusion of the Second National SME Development Council Meeting. [Online] Available: http://www.bnm.gov.my/ index.php?ch=8\&pg=14\&ac=943 (11, 12, 2009)

Barnes, C. (1996). Assets and the Impact of Microenterprise Finance Programs. Assessing the Impact of Microenterprise Services, Washington DC: Management Systems International. [Online] Available: http://www.microfinancegateway.org/gm/document-1.9.28636/28008_file_13.pdf $(13,05,2008)$

Chen, M.A. and Dunn, E. (1996). Household Economic Portfolios. Assessing the Impact of Microenterprise Services, Washington DC: Management Systems International. [Online] Available: http://www.uncdf.org/mfdl/readings/HHecoPF.pdf $(25,11,2009)$

Dunn, E. and Arbuckle, J.G. (2001). The Impact of Microcredit; a Case Study from Peru. Assessing the Impact of Microenterprise Services Paper, Washington DC: Management Systems International. [Online] Available: http://pdf.usaid.gov/pdf_docs/PNACN574.pdf (04, 12, 2009) 
Gibbons, D. S. and Kasim, S. (1990). Banking on the Rural Poor. Center for Policy Research, University Science Malaysia, Malaysia.

Hossain, M. (1988). Credit for the Alleviation of Rural Poverty: The Grameen Bank in Bangladesh. Research Report No. 55, IFPRI, Washington, D.C.

Hulme, D. (1997). Impact Assessment Methodologies for Microfinance: A Review. CGAP Working Group on Impact Assessment, CGAP, Washington D.C.

Hulme, D. (2000). Impact assessment methodologies for microfinance: theory, experience and better practice. World Development, Vol. 28(1), pp. 79-98. http://dx.doi.org/10.1016/S0305-750X(99)00119-9

Islam, T. (2007). Microcredit and poverty alleviation. Aldershot, England; Burlington, U.S.A.: Ashgate Publishing.

Kamal, M. M. (1999). Measuring Transformation: Assessing and Improving the Impact of Microcredit. Discussion Paper, Impact Evaluation Mechanism, Association for Social Advancement (ASA), Dhaka, Bangladesh. [Online] Available: http://www.strategicnetwork.org/pdf/kb8406.pdf (12,10,2010)

Khandker, S.R. and Pitt, M. (1998). The Impact of Group-Based Credit Programs on Poor Households in Bangladesh: Does the Gender of Participants Matter? Journal of Political Economy, Vol. 106, pp. 958-996. http://dx.doi.org/10.1086/250037

Montgomery, H. and Weiss, J. (2011). Can Commercially-oriented Microfinance Help Meet the Millennium Development Goals? Evidence from Pakistan. World Development, Vol. 39 (1), pp. 87-109. http://dx.doi.org/10.1016/j.worlddev.2010.09.001

Mosley, Paul. (1996). Metamorphosis from NGO to Commercial Bank: The Case of Bancosol in Bolivia. Finance Against Poverty, Volume II: Country Case Studies, edited by David Hulme and Paul Mosley, 1-45. London: Routledge.

Panda K. D. (2009). Participation in the Group Based Microfinance and its Impact on Rural Households: A Quasi-experimental Evidence from an Indian State. Global Journal of Finance and Management, Vol. 1(2), pp. 171-183.

Rahman, S., Rafiq, R. B. and Momen, M. A. (2009). Impact of Microcredit Programs on Higher Income Borrowers: Evidence from Bangladesh. International Business \& Economics Research Journal, Vol. 8(2), pp: 119-124

Robinson M. (2001). The Microfinance Revolution: Sustainable Finance for the Poor. International Bank for Reconstruction and Development/The World Bank Washington D.C. [Online] Available: http://www-wds.worldbank.org/ (11.02.2008)

Saad, M. N. (2010). Achieving Human Development Objectives through Microfinance Institution: The case of Amanah Ikhtiar Malaysia. Journal of Islamic Economics, Banking and Finance, Vol. 6 (2), pp. 65-78.

Saad, M. N. (2011). Selecting High-Income Generating Activities for Micro-entrepreneurs: The Case Study of Amanah Ikhtiar Malaysia. International Journal of Humanities and Social Science, Vol. 1 (5), pp. 258-264.

Salma M. (2004). A Comparative Case Study on Outreach and Impact of Ikhtiar Loan Scheme and Special Program for Hardcore Poor in Seberang Perai Pulau Pinang. Center of Policy Research, University Sains Malaysia.

Sebstad, J and Walsh, M. (1991). Microenterprise Credit and its Effects in Kenya: An Exploratory Study. Report prepared for USAID AFR/MDI and S\&T/WID. Coopers and Lybrand, Washington, D.C.

Second Internal Impact Study. (1990). Research and Development Unit, Amanah Ikhtiar Malaysia, Selangor, Malaysia.

SERU - Social Science and Economic Research Unit. (1990). Impact Study. Prime Ministers Department, Malaysia

Swain, R. B. and Varghese, A. (2009). Does Self Help Group Participation Lead to Asset Creation? World Development, Vol. 37(10), pp. 1674-1682. http://dx.doi.org/10.1016/j.worlddev.2009.03.006

Sutoro, A. D. (1990). KUPEDES Development Impact Survey: Briefing Booklet, Planning, Research and Development Department. BRI, Indonesia.

Third Internal Impact Study. (1994). Research and Development Unit, Amanah Ikhtiar Malaysia, Selangor, Malaysia.

USAID. (2011). USAID and Microenterprise Development. [Online] Available: http://www.usaid.gov/ our_work/economic_growth_and_trade/micro/index.html $(12,01,2011)$ 
Table 1. Participation and Uses of Loan

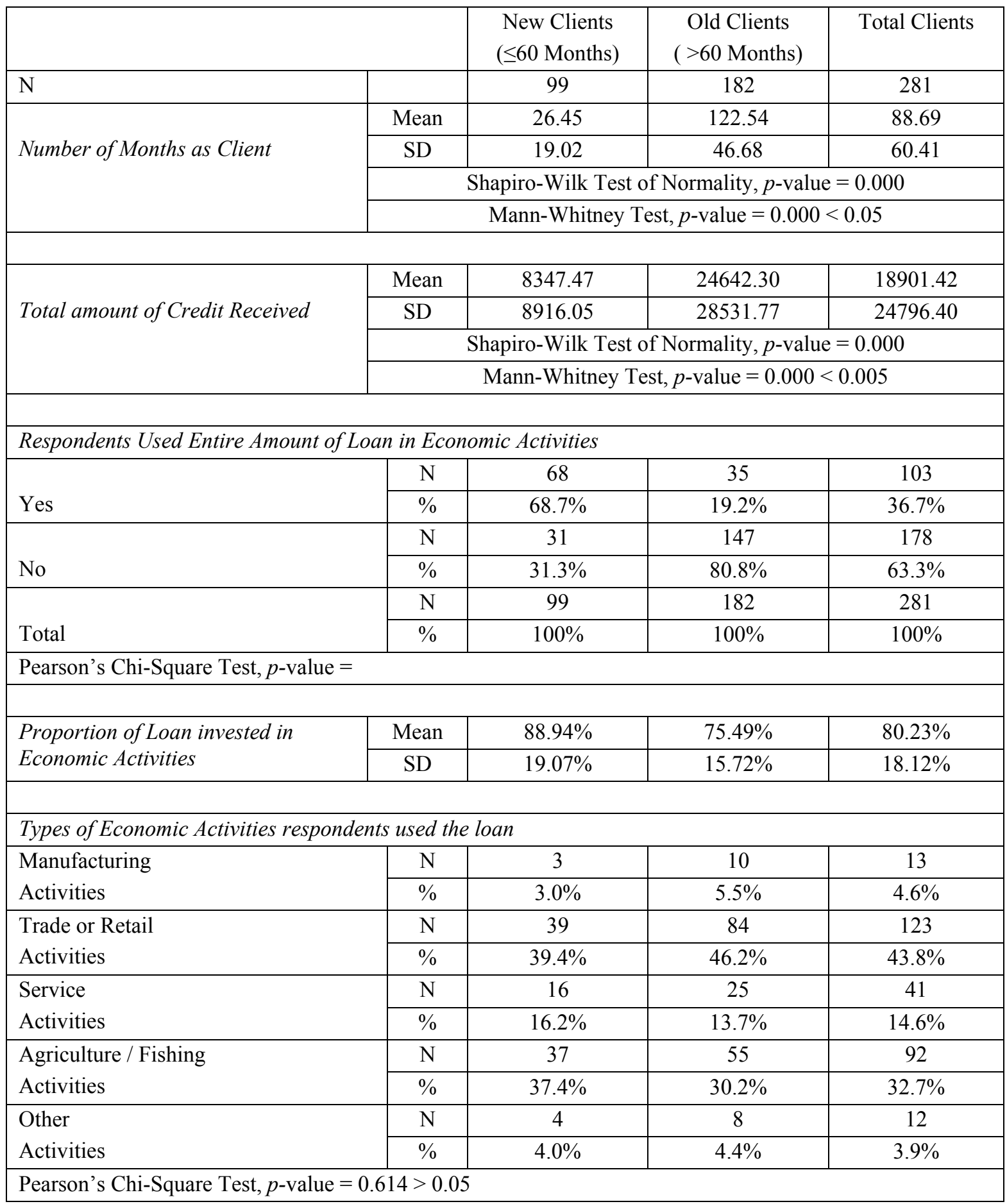


Table 2. Microenterprise Assets, Savings and Unpaid loan

\begin{tabular}{|c|c|c|c|c|}
\hline & & $\begin{array}{l}\text { New Clients } \\
\text { ( } \leq 60 \text { Months) }\end{array}$ & $\begin{array}{c}\text { Old Clients } \\
(>60 \text { Months })\end{array}$ & Total Clients \\
\hline $\mathrm{N}$ & & 99 & 182 & 281 \\
\hline \multirow{4}{*}{ Current Market Value of Livestock's } & $\mathrm{N}$ & 7 & 22 & 29 \\
\hline & $\%$ & 7.1 & 12.1 & 10.3 \\
\hline & Mean & 3965.14 & 7122.18 & 6360.13 \\
\hline & SD & 2926.00 & 7271.40 & 6586.33 \\
\hline \multirow{4}{*}{$\begin{array}{l}\text { Current Market Value of } \\
\text { Agricultural / Production } \\
\text { Equipments }\end{array}$} & $\mathrm{N}$ & 9 & 15 & 24 \\
\hline & $\%$ & 9.1 & 8.2 & 8.5 \\
\hline & Mean & 666.66 & 2350.00 & 1718.75 \\
\hline & SD & 324.03 & 5049.18 & 4030.85 \\
\hline \multirow{4}{*}{$\begin{array}{l}\text { Current Market Value of } \\
\text { Agricultural Stock / Raw Materials }\end{array}$} & $\mathrm{N}$ & 33 & 43 & 76 \\
\hline & $\%$ & 33.3 & 23.6 & 27.0 \\
\hline & Mean & 3061.81 & 7960.27 & 5833.31 \\
\hline & SD & 3060.81 & 7684.21 & 6560.26 \\
\hline \multirow{4}{*}{$\begin{array}{l}\text { Current Market Value of Enterprise } \\
\text { Assets }\end{array}$} & $\mathrm{N}$ & 50 & 123 & 163 \\
\hline & $\%$ & 50.5 & 62.1 & 58.0 \\
\hline & Mean & 5724.70 & 10541.92 & 9064.24 \\
\hline & SD & 3910.80 & 8859.07 & 7990.70 \\
\hline \multirow{4}{*}{ Current Market Value of Vehicles } & $\mathrm{N}$ & 80 & 130 & 210 \\
\hline & $\%$ & 80.8 & 71.4 & 74.7 \\
\hline & Mean & 7347.50 & 8366.15 & 7978.09 \\
\hline & SD & 5632.90 & 8086.90 & 7252.90 \\
\hline \multirow{4}{*}{ Current Market Value of Orchard } & $\mathrm{N}$ & 13 & 14 & 27 \\
\hline & $\%$ & 13.1 & 7.7 & 9.6 \\
\hline & Mean & 3192.30 & 3057.14 & 3122.22 \\
\hline & SD & 2556.51 & 2506.82 & 2482.60 \\
\hline \multirow{2}{*}{$\begin{array}{l}\text { Total Savings in Group } \\
\text { Fund }\end{array}$} & Mean & 446.36 & 758.62 & 681.17 \\
\hline & SD & 171.93 & 989.52 & 988.29 \\
\hline \multirow{4}{*}{ Unpaid Loan Received from AIM } & $\mathrm{N}$ & 73 & 136 & 209 \\
\hline & $\%$ & 73.7 & 74.7 & 74.4 \\
\hline & Mean & 3059.68 & 5986.36 & 4964.12 \\
\hline & SD & 3335.73 & 7604.60 & 6583.44 \\
\hline
\end{tabular}

Table 3. Mean Difference in Microenterprise Assets

\begin{tabular}{|l|c|c|c|}
\hline & $\begin{array}{c}\text { New Clients } \\
(\leq 60 \text { Months })\end{array}$ & $\begin{array}{c}\text { Old Clients } \\
(>60 \text { Months })\end{array}$ & Total Clients \\
\hline $\mathrm{N}$ & 96 & 172 & 14577.60 \\
\hline Mean & 10947.19 & 16603.87 & 10221.71 \\
\hline Standard Deviation & 6945.95 & 1171.76 & \\
\hline Shapiro-Wilk Test of Normality, $p$-value $=0.000<0.05$ & \\
\hline Mann-Whitney Test & 108.52 & 149.00 \\
\hline Mean Rank & \multicolumn{2}{|c|}{$0.000<0.05$} \\
\hline$Z$ - value & \multicolumn{2}{|c|}{} \\
\hline$p$-value & \multicolumn{2}{|c|}{} \\
\hline
\end{tabular}

